Article

\title{
Defining Priority Land Covers that Secure the Livelihoods of Urban and Rural People in Ethiopia: a Case Study Based on Citizens' Preferences
}

\author{
Marine Elbakidze ${ }^{1, *}$, Mersha Gebrehiwot ${ }^{2}$, Per Angelstam ${ }^{1}$, Taras Yamelynets ${ }^{3}$ \\ and Diana Surová 4 (iD \\ 1 School for Forest Management, Faculty of Forest Sciences, Swedish University of Agricultural Sciences, \\ P.O. Box 43, 73921 Skinnskatteberg, Sweden; per.angelstam@slu.se \\ 2 Wondo Genet College of Forestry and Natural Resources, Hawassa University, Shashemene 128, Ethiopia; \\ mershagebrehiwot@gmail.com \\ 3 Faculty of Geography, Ivan Franko National University, Doroshenko Street 41, 79000 Lviv, Ukraine; \\ taras.yamelynets@gmail.com \\ 4 Instituto de Ciências Agrárias e Ambientais Mediterrânicas (ICAAM), Universidade de Évora, \\ Núcleo da Mitra, Apartado 94, 7006-554 Évora, Portugal; dj@uevora.pt \\ * Correspondence: marine.elbakidze@slu.se; Tel.: +46-722-96-3167
}

Received: 30 January 2018; Accepted: 18 May 2018; Published: 23 May 2018

\begin{abstract}
Securing land management systems that maintain land covers is important for sustaining human livelihoods in Africa; however, simultaneously maintaining a viable natural environment is a serious challenge. Aggravated by rapid population growth and biodiversity loss, Ethiopia is an illustrative example of this issue. Stressing the need for a bottom-up stakeholder perspective, we identify and map land covers that deliver multiple ecosystem services that are important for the livelihoods of rural and urban citizens in the southern part of Ethiopia's Rift Valley. First, we interviewed 400 urban and rural residents to identify the land covers that deliver desired ecosystem services in three agroecological zones, representing a steep gradient in the livelihood conditions. Second, to support the inclusion of priority land covers in spatial planning, we located spatial concentrations of individual land covers providing bundles of desired ecosystem services. The majority of urban respondents selected homegarden agroforestry $(92 \%$ of respondents from this group), freshwater lake $(82 \%)$, river $(70 \%)$, agroforestry shade-grown coffee $(65 \%)$, natural old-growth forest $(59 \%)$, rural settlement $(52 \%)$, Afromontane undifferentiated forest $(52 \%)$, and urban areas $(73 \%)$ as important for their livelihood. In contrast, the majority of rural respondents selected three land covers: homegarden agroforestry ( $80 \%$ of respondents from this group), agroforestry shade-grown coffee (58\%), and urban areas (65\%). To maintain the identified natural and semi-natural priority land covers, at least two land management strategies are crucial to sustain the provision of ecosystem services for the livelihoods of both urban and rural people, and biodiversity conservation: (1) maintaining traditional agroforestry land-use practices, and (2) enhancing the protection and sustainable management of natural forest ecosystems. Additionally, integrated spatial planning is needed that considers both rural local community-based resource management that focuses on local needs for employment and products, and global demands to conserve biodiversity.
\end{abstract}

Keywords: ecosystem services; sustainable livelihood; biodiversity; traditional land use

\section{Introduction}

In Africa, due to the deterioration and loss of biodiversity and land degradation, multiple ecosystem services that are important for human livelihoods have been declining or lost, thus affecting 
citizens' daily lives and hampering social and economic development [1]. According to the Millennium Development Goals report [2], during the period of 2011-2013, Sub-Saharan Africa was the most food-deficient region in the world, with $25 \%$ of the population facing hunger and malnutrition. It is estimated that a quarter of the African population will still live under extreme poverty in 2030 [3]. Additionally, Africa is one of the most vulnerable continents to climate change [1,4]. Sustaining land management systems that improve human livelihoods while maintaining a viable environment and biodiversity is thus a serious challenge in Africa [5,6]. Ethiopia is one example of such African countries.

In Ethiopia, a third of the population live in absolute poverty, meaning people who are severely deprived of basic needs, including food, safe drinking water, healthcare, and shelter [7,8]. The country has been increasingly challenged by high population growth, droughts, diseases, and environmental deterioration [9]. Close to 15 million people live in drought-prone lowland areas where extremely high temperatures, increased rainfall variability, shortage of water, loss of dry-season pastures, and the degradation of natural resources undermine rural livelihoods. As a result, about half of the population is chronically food-insecure and rely on food aid, even in years with sufficient rainfall [10]. In the Ethiopian highlands, a shortage of farmland, deforestation, and land degradation are critical obstacles for improving human livelihoods [11,12].

Biodiversity loss is another major problem. Ethiopia has the fifth largest floral diversity in tropical Africa [13]. Different types of natural ecosystems in Ethiopia provide various economic, ecological, and social values for the livelihoods of both rural and urban citizens. However, the diverse and rich natural ecosystems are vanishing at an alarming rate due to widespread deforestation and land degradation [1]. For example, historical evidence reveals that, from the beginning of the 20th century, the Ethiopian natural forest has declined from $40 \%$ of the total country's territory to less than $3 \%$ in 2007 [14]. Both the expansion and intensification of agriculture, as well as ongoing urbanization, lead to habitat loss that threatens biodiversity and the supply of tangible services such as food, water, and energy, in addition intangible services such as sacred sites and religious spaces that are central to a multitude of livelihood strategies $[1,15,16]$. However, as in many other countries with a long land-use history, natural ecosystems have also been transformed to multifunctional cultural woodlands. There are varieties of traditional practices that deliver multiple benefits, including diverse agricultural products. Currently, traditional small-scale agriculture is the dominant practice in Ethiopia. However, this type of land use is challenged by land degradation and fragmentation and low agricultural production [17-19], which are critical obstacles for improving rural livelihoods [20].

Ethiopia has endorsed the Strategic Environmental Assessment for the purpose of mainstreaming biodiversity and ecosystem services into political and management decisions at the strategic level, as well as into spatial planning [21,22]. However, there is a lack of studies that define what ecosystem services are important for the livelihoods of the rural and urban populations in Ethiopia, and in Africa in general. This applies to both the supply and demand of ecosystem services. However, the latter is often casually handled [23]. Instead the majority of studies focuses mainly on the supply side of ecosystem services by mapping ecosystem components based on the quantification of ecological properties to provide a certain service, using spatial analyses of different land covers and other spatially explicit data [24-26]. However, recent studies also demonstrate the importance of addressing the demand side of ecosystem services [27] in terms of the perspectives and interests of the public or diverse stakeholders on ecosystem services, and consequences for their livelihoods [28,29]. Additionally, the subsequent literature viewed ecosystem services in the economic sense, valuing the ecosystem services' need to encompass all forms of values [30-36], rather than depend only on the availability/non-availability of markets [37]. This narrow economic valuation, together with a consumptive view of ecosystem services, may lead to a dangerous commodification of ecosystem services.

Moreover, at present, there is much rhetoric at different levels about securing livelihoods in African countries. However, approaches to deal with this complex and multidimensional issue have primarily been designed and developed by researchers at a distance or from above [38,39]. In addition, 
bottom-up approaches are needed [40]. There are numerous studies on land-cover and land-use change that were conducted for different regions in Ethiopia [41-43], which have focused mainly on the drivers and consequences of land-use/land-cover change for human livelihoods.

Thus, there is an urgent need for comprehensive studies on what ecosystem services people need for their livelihoods, and what types of natural and semi-natural areas deliver the demanded ecosystem services. A recent comparative study on environmental income in developing countries, including Africa, confirmed that natural forests and other land covers play a critical role in rural livelihoods [44]. Empirical studies that can support policymakers' and planners' work to establish priorities in the use and conservation of biodiversity and related ecosystem services are therefore crucial. This involves the identification of land management strategies that can maintain and enhance both natural and semi-natural cultural landscapes that deliver bundles of ecosystem services that are important for the livelihoods of both urban and rural citizens, while also maintaining biodiversity in Ethiopia.

The aim of this study is to identify and map land covers that deliver multiple ecosystem services that are important for the livelihoods of rural and urban citizens in Ethiopia using a bottom-up method [45]. We focus only on the demand side of the ecosystem service concept, and therefore, on the beneficiaries of ecosystem services. This study is an attempt to elucidate people's "appreciation" [46] of a suite of ecosystem services linked to different land covers. First, we interviewed 400 urban and rural residents to identify the land covers that deliver desired ecosystem services in three agroecological zones, representing a steep gradient in livelihood conditions in Ethiopia's Rift Valley Sidama zone, which was chosen as the study area. Second, to support the inclusion of priority land covers in spatial planning, we located spatial concentrations of individual land covers providing multiple ecosystem services. Finally, we combined the ecosystem service concept [47] and the sustainable livelihood approach [48] to discuss what land covers and land management strategies maintain assets that are important to the livelihoods of respondents.

\section{Methodology}

\subsection{Sustainable Livelihood Approach}

We use the sustainable livelihoods approach (SLA) [48] as a framework to understand the role that bundles of ecosystem services delivered by different land covers have in securing the livelihoods of both urban and rural residents in Ethiopia. Ecosystem services are the benefits that people obtain, either directly or indirectly, from ecosystems [47]. These include provisioning, regulating, cultural, and supporting services. The SLA is a widespread tool that is used to examine complex rural livelihood issues from a local-level perspective [39,49]. Since the introduction of the SLA, it has been defined and modified by different scholars and development agencies in order to adapt and apply it to different context-specific needs and circumstances [50-52]. A livelihood comprises the assets, the activities, and the access to these (mediated by institutions and social relations) that together determine the living gained by the individual and household [48].

There are five assets that are important for maintaining sustainable livelihoods: (1) natural capital, which represents natural resources such as land, water, and biological goods; (2) social capital, which refers to the institutions, relationships, and norms that shape the quality and quantity of social interaction; (3) economic/financial capital, or the financial resources that people use to achieve their livelihood objectives; (4) human capital, representing the skills, knowledge, experience, ability to work, and good health as well as household relations that together enable people to pursue their livelihood strategies; and (5) physical, or man-made, capital such as transport, shelter, road, market, adequate drainage facilities, electricity, and telecommunications $[48,53,54]$. To understand the contributions of different land covers to the livelihoods of both urban and rural residents in the study area, we made an attempt to understand the relations among four categories of ecosystem services delivered by natural and semi-natural areas and the SLA's capital (further detailed in Section 2.4). 


\subsection{Study Area}

The Sidama zone $\left(5^{\circ} 45^{\prime}-6^{\circ} 45^{\prime} \mathrm{N} ; 38^{\circ} 15^{\prime}-39^{\circ} 00^{\prime \prime}\right.$ E) (hereafter referred to as Sidama) in the Rift Valley of Ethiopia's Southern Nations', Nationalities', and Peoples' Regional State (SNNPRS) (Figure 1) was selected as the study area. It covers $6538 \mathrm{~km}^{2}$, with a human population of 3.4 million. Sidama represents a diversity of biophysical conditions, cultural land-use practices, and current challenges to achieving the sustainable livelihood of both the rural and urban populations that are specific to Sub-Saharan Africa. Such challenges include, for example, rapid population growth, deterioration and loss of biodiversity, shortage of farmland, and land degradation.

This region is the most densely populated area in southern Ethiopia, with a population density of 520 persons per $\mathrm{km}^{2}$ [55]. Sidama is divided into 19 administrative Weredas (i.e., sub-districts) and 532 kebele associations (KAs) (i.e., villages). Sidama people are Cushitic families, who form part of a great Cushitic civilization [56], which is one of the ancient groups living in their traditional environment with internal and external population migration. Sidama people have distinct traditions for solving problems between individuals and within rural communities [57].

The Rift Valley of East Africa dissects Sidama into western lowlands and eastern highlands. The study area is partly bounded by the steep escarpments between the highlands and its foothills in the Rift Valley. The valley floor is covered by alluvial plains, and includes Lake Hawassa and the wetlands of the former Lake Cheleleka [58]. By the end of the 19th century, Sidama was covered mainly by natural forest, including savannah woodland with scattered trees and grassland. At present, forest and woodland cover approximately $3 \%$ [58].

The climatic conditions in Sidama range from hot and dry desert in the lowland areas to cold and humid alpine habitats in the highlands. The natural vegetation ranges from dry semi-deciduous forest (450-600 m) via transitional rain forest (500-1500 m) to the Afromontane forest (1500-2600 m) [59] with wild Arabica coffee (Coffee arabica) [59-61]. The increasing flooding and sedimentation due to deforestation and land degradation seriously affect the water and soil resources of the study area. Sidama is divided into three agroecological zones with different climates linked to altitude: arid Dega, sub-tropical Woyna Dega, and cold Qolla (Figure 1 and Table 1).
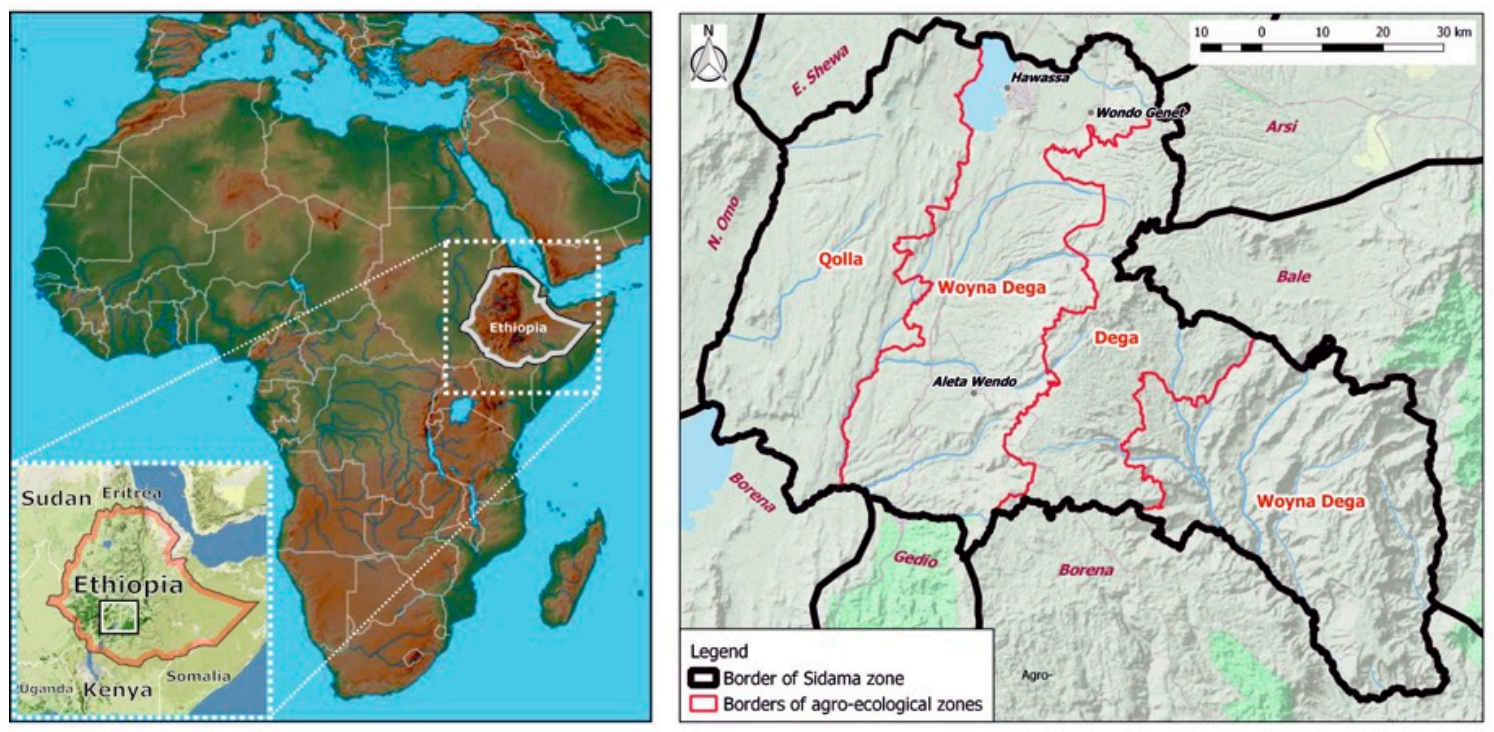

Figure 1. The location of Ethiopia in Africa (left) and the location of the Sidama zone with the three agroecological zones in Ethiopia (right). 
Table 1. Main characteristics of agroecological zones in the Sidama zone.

\begin{tabular}{lccc}
\hline & \multicolumn{3}{c}{ Agroecological Zone } \\
\cline { 2 - 4 } & $\begin{array}{c}\text { Dega } \\
\text { (Stratum I) }\end{array}$ & $\begin{array}{c}\text { Woyna Dega } \\
\text { (Stratum II) }\end{array}$ & $\begin{array}{c}\text { Qolla } \\
\text { (Stratum III) }\end{array}$ \\
\hline Size, ha & 116,734 & 392,050 & 179,583 \\
Altitude range, $\mathrm{m}$ & $2500-3500$ & $1500-2500$ & $500-1500$ \\
Annual rainfall, mm & $1200-1800$ & $1000-1800$ & $400-800$ \\
Mean annual temperature, ${ }^{\circ} \mathrm{C}$ & $10-15$ & $15-20$ & $20-25$ \\
\hline
\end{tabular}

\subsection{Structured Interviews}

A total of 400 structured face-to-face interviews were conducted from December 2015 to July 2016. To capture the spatial variability of the land covers in the study area, we first stratified the human population by the type of agroecological zone in which they live. Accordingly, three sampling strata for rural and urban respondents were identified: arid Dega as stratum I, sub-tropical Woyna Dega as stratum II, and cold Qolla as stratum III (Table 1). The fourth URBAN stratum was represented by people living in 10 randomly selected municipal centers of the study area, including Hawassa, which is the capital of SNNPRS. The interviews were evenly distributed among the four defined strata. The respondents were randomly chosen, and their gender and age were balanced during the process of data collection.

The questionnaire was developed using Survey Monkey software (www.surveymonkey.com). It consisted of three blocks of questions. In the first block, respondents were asked to select ecosystem services that were important for their personal livelihood from a predetermined list of ecosystem services using four options: 'important', 'slightly important', 'not important', and 'don't know'. The list of ecosystem services was based on the four categories, i.e., provisioning, cultural, regulating, and supporting services. This block of questions was important in order to prepare respondents mentally to provide comprehensive answers to the last block of questions, which were related to the perceived tangible and intangible contributions of different land covers to their personal livelihood. To avoid confusion, especially concerning regulating and supporting services, the meaning of each ecosystem service was clearly introduced to respondents with explanations and examples.

Perceptions of different land covers' role for livelihoods depended on a wide range of factors, such as age, gender, place of residence, and experiences [62]. Hence, the second block of questions brought up the respondents' personal data, including place of residence, education, occupation, rural/urban area, type of property of the respondent, age, time lived in the specific location, and gender.

In the third and final block, we employed a visual preference survey using photographs of the dominant land covers in the study area in order to identify and examine how different respondents interpret the use and values of various land covers in relation to ecosystem services that are important for their livelihoods. All of the photos were captured in the study area in December 2015. Unlike interviews or questionnaire surveys, the use of photos is impregnated with a set of layered meanings related directly to people's lives, knowledge, and experiences in relation to a specific landscape or location [62]. In total, 24 A4-size photographs that represented the different land covers of the study area were presented to each respondent. The photographs captured the gradient from natural and semi-natural land covers to built infrastructure across the three agroecological zones. Respondents were asked to choose from the 24 alternatives up to eight land-cover photos that they perceived as important for their livelihood. After respondents selected the photos, they were asked to describe what benefits each selected land cover provided for their livelihood (Figure 2). Their answers were then transformed into the ecosystem services and recorded in the questionnaire. Finally, respondents were asked to select the most unwanted land cover, and explain a reason for this selection. Additionally, valuable comments provided by respondents were recorded. 


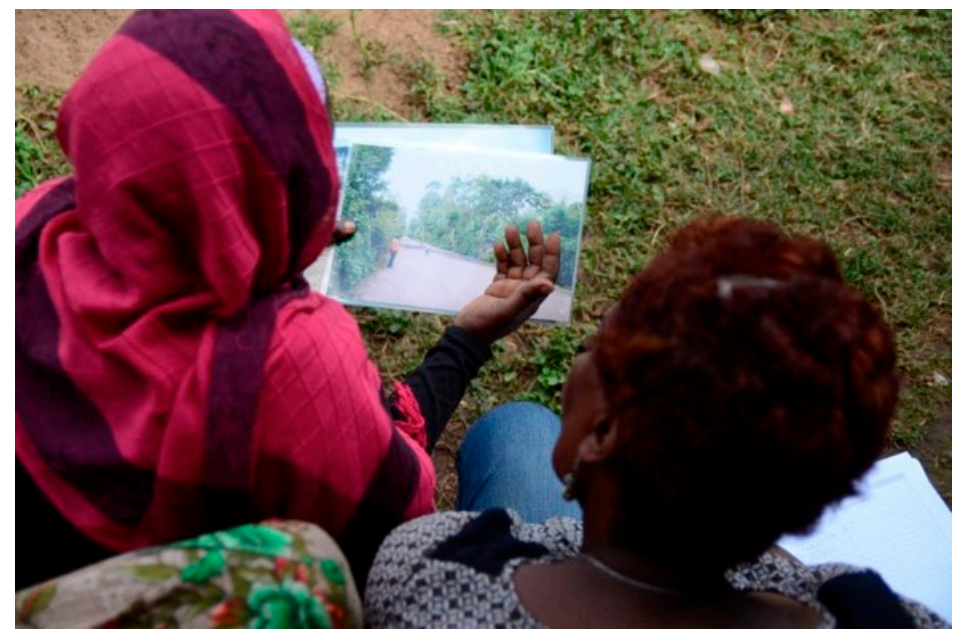

Figure 2. Mersha Gebrehiwot interviewing a female respondent in Sisha village in the study area. Photo by Marine Elbakidze.

The sample of respondents consisted of $47 \%$ women and $53 \%$ men. Respondents were from urban $(45 \%)$ and rural (55\%) areas. Their age ranged from 18 to 77 years. In total, 30\% of the respondents were employed, $53 \%$ were self-employed, $6 \%$ were unemployed, $8 \%$ were students, and $3 \%$ were retired. The education level of respondents ranged from no education to doctoral degrees from universities.

\subsection{Data Analysis}

The data for the analysis of ecosystem services that were considered important for the livelihoods of urban and rural respondents were organized in excel files by Survey Monkey software. To test the statistical significance of any differences between the preferences of rural and urban respondents regarding ecosystem services that were important for their personal livelihood, we applied the Pearson chi-square test using the IBM SPSS Statistics 24 software [63]. It is a commonly used test for testing relationships between categorical variables. As a decision rule to assess whether there were statistical differences between rural and urban respondents concerning ecosystem services, we considered the $p$-value in the Pearson chi-square test. If $p \leq 0.05$, the test was significant (indicating a significant difference in the perception of the particular ecosystem service). If $p>0.05$, there was not a significant difference between rural and urban residents. We also calculated Cramer's V-test, which is a measure of the association between two categorical variables. It varies from 0 (corresponding to no association between the variables) to 1 (complete association). When the Cramer's $V$ value is $\leq 0.10$, the effect size is small. If the Cramer's V value is $\leq 0.20$ and $>0.20$, the effect size is medium and large, respectively.

To identify priority land covers, we analyzed the interview data to identify those photos that were selected by the majority ( $>50 \%$ ) of rural and urban respondents separately. After that, we matched each selected photo with a specific land-cover type using existing spatial vector and raster data. ArcGIS 10.3 software and QGIS 2.16 [64] were used to extract and analyze the data. Satellite images (Landsat 8, 2013-2016, spatial resolution $30 \mathrm{~m}$ ), digital elevation data (Landsat 8, DEM), topographic maps, and vegetation maps of the region were used to identify the location of each priority land cover. The geographic information systems (GIS) database of Hawassa University's Wondo Genet College of Forestry and Natural Resources (WGCFNR) was used to determine the spatial location of rivers, lakes, and administrative borders of Weredas in Sidama. We used the GIS database and field research data of WGCFNR to elaborate the vector layer representing degraded land in Sidama.

We also applied a "hotspot" analysis to identify the location of statistically significant priority land covers by calculating the Getis-Ord $\mathrm{Gi}^{*}$ statistic [64] for each priority land cover in our dataset. First, we created a $0.1 \times 0.1 \mathrm{~km}$ raster, and calculated the area of each priority land cover within each grid cell. These input data were used to calculate the resulting z-score and $p$-value. To be a statistically 
significant hotspot, a priority land cover must have a high value and be surrounded by other land covers with high values. The statistical variable $\mathrm{Gi}^{*}$, which was assigned to each of the $0.5 \times 0.5 \mathrm{~km}^{2}$ grid cells in the dataset, is the z-score. For statistically significant positive z-scores, the higher the z-score, the more intense the clustering of high values (hotspots). As a result, we created maps with a z-score, $p$-value, and a reliability level (Gi_Bin) for each $0.5 \times 0.5 \mathrm{~km}^{2}$ grid cell. The Gi_Bin field was defined at the statistical significance of hotspots \pm two bins, which represented a confidence level of $90 \%$. The output map shows the location of the most statistically significant land covers.

To understand the contributions of priority land covers to the livelihoods of the respondents, each specific ecosystem service delivered by each priority land cover was connected to a specific capital. In many cases, the connections were obvious. For example, water circulation (a regulating service), habitat for species (a supporting service), and medicinal plants (a provisioning service) belong to natural capital (Table 2). Regarding social and human capital, several provisioning services, for example, food from homegarden agroforestry, are connected to three assets-natural, human, and social-because the delivery of these ecosystem services requires natural resources (natural capital) as well as traditional knowledge (human capital) and social interactions among farmers (social capital), as acknowledged by respondents. Economic capital was related to provisioning services only in those cases when respondents indicated that they produced food, fodder, or collected non-wood forest products for sale. Contributions of ecosystems to human health as a cultural service were related to human capital, while religious and spiritual values, traditional knowledge, and cultural heritage values were associated with both human and social capital. Regarding physical capital, when a respondent selected any built-up land cover, we documented that physical capital was important for his/her livelihood; however, it was not delivered by ecosystems, and thus was not documented as an ecosystem service.

Table 2. Relations among the four categories of ecosystem services and five assets of sustainable livelihoods. Grey color indicates connections among categories of ecosystem services and the assets of sustainable livelihoods.

\begin{tabular}{lllll}
\hline \multirow{2}{*}{ Assets of Sustainable Livelihoods } & \multicolumn{3}{c}{ Categories of Ecosystem Services } \\
\cline { 2 - 4 } & Supporting & Regulating & Provisioning & Cultural \\
\hline Natural capital & & & \\
Social capital & & & \\
Economic capital & & & \\
Human capital & & & \\
Physical capital & & & \\
\hline
\end{tabular}

\section{Results}

\subsection{Ecosystem Services for Livelihoods of Urban and Rural Respondents}

According to the Pearson chi-square tests, from the list of 47 ecosystem services, rural and urban respondents did not differ in evaluating 24 of the listed ecosystem services. However, in the remaining 23 ecosystem services, the perceptions of rural and urban respondents were significantly different (Figure 3 and Table 3). Urban respondents were more likely to say that the several cultural services (e.g., recreation and ecotourism, education, and knowledge), provisioning services (e.g., fish, wind energy, fiber for paper, bio-energy), regulating services (e.g., global climate regulation, pollination, seed dispersal), and supporting services (habitat for species, species, and protection against natural disturbances) were perceived as important for their personal livelihoods. On the contrary, rural residents were more likely to say that one of the cultural services (spiritual and religious values) and several provisioning services (food commercial, fresh water for irrigation, timber, and fodder for own consumption) were important. Most associations had a large size effect $(>20)$. The largest Cramer's V was observed in fodder for own consumption, following by fish and food for commercial purposes. 
Table 3. Results from the Pearson chi-square tests with the list of the ecosystem services differently $(p<0.05)$ evaluated by rural and urban residents. The calculation of the tests considered all of the levels of importance. In the table, we report only the counts and expected values for "important" level, where the major differences between rural and urban residents were observed.

\begin{tabular}{|c|c|c|c|c|c|c|c|c|}
\hline \multirow[b]{3}{*}{ Ecosystem Services } & \multicolumn{4}{|c|}{ Category "Important" for Ecosystem Service } & \multirow{3}{*}{ Value } & \multirow{3}{*}{\multicolumn{2}{|c|}{$\begin{array}{l}\text { Pearson Chi-Square Test } \\
\text { Asymptotic Significance (2-Sided), } p \text {-Value }\end{array}$}} & \multirow{3}{*}{$\begin{array}{c}\text { Symmetric Measure } \\
\text { Cramer's V }\end{array}$} \\
\hline & \multicolumn{2}{|r|}{ Rural } & \multicolumn{2}{|r|}{ Urban } & & & & \\
\hline & Count & Expected Count & Count & Expected Count & & & & \\
\hline Recreation and ecotourism & 26 & 47.2 & 108 & 86.8 & 35.474 & 2 & 0 & 0.32 \\
\hline Education and knowledge & 14 & 27.8 & 65 & 51.2 & 14.621 & 2 & 0.001 & 0.204 \\
\hline Spiritual and religious values & 86 & 77 & 132 & 141 & 24.66 & 3 & 0 & 0.265 \\
\hline Food: commercial & 77 & 56 & 82 & 103 & 60.488 & 3 & 0 & 0.415 \\
\hline Fish & 16 & 60.6 & 155 & 110.4 & 99.918 & 2 & 0 & 0.534 \\
\hline Fresh water: irrigation & 62 & 49.7 & 79 & 91.3 & 23.384 & 3 & 0 & 0.259 \\
\hline Wild medicine (wild plants, animals) & 1 & 9.5 & 26 & 17.5 & 13.416 & 3 & 0.004 & 0.196 \\
\hline Wind energy & 3 & 15.1 & 40 & 27.9 & 37.771 & 3 & 0 & 0.329 \\
\hline Fiber/paper & 0 & 14.7 & 42 & 27.3 & 51.769 & 3 & 0 & 0.384 \\
\hline Mineral resources & 0 & 6.2 & 18 & 11.8 & 15.353 & 3 & 0.002 & 0.211 \\
\hline Timber & 66 & 53.4 & 86 & 98.6 & 17.551 & 3 & 0.001 & 0.224 \\
\hline Bio-energy & 7 & 23.8 & 61 & 44.2 & 39.784 & 3 & 0 & 0.338 \\
\hline Fodder: for own consumption & 107 & 64.5 & 77 & 119.5 & 101.892 & 3 & 0 & 0.541 \\
\hline Biochemical and genetic resources & 10 & 32.3 & 82 & 59.7 & 36.568 & 3 & 0 & 0.325 \\
\hline Climate regulation: global & 27 & 43.6 & 97 & 80.4 & 18.029 & 3 & 0 & 0.227 \\
\hline Water purification and waste treatment & 18 & 32 & 73 & 59 & 13.817 & 3 & 0.003 & 0.199 \\
\hline Water regulation & 26 & 38.4 & 83 & 70.6 & 9.378 & 3 & 0.025 & 0.163 \\
\hline Pollination & 3 & 12.9 & 34 & 24.1 & 25.359 & 3 & 0 & 0.269 \\
\hline Seed dispersal & 1 & 8.5 & 23 & 15.5 & 19.895 & 3 & 0 & 0.238 \\
\hline Water circulation & 29 & 37.6 & 78 & 69.4 & 8.091 & 3 & 0.044 & 0.152 \\
\hline Primary production & 2 & 8 & 21 & 15 & 13.321 & 3 & 0.004 & 0.196 \\
\hline Photosynthesis & 21 & 50.7 & 121 & 91.3 & 47.528 & 3 & 0 & 0.37 \\
\hline Habitat for species & 66 & 78.5 & 158 & 145.5 & 9.854 & 3 & 0.02 & 0.168 \\
\hline Species & 40 & 64.5 & 142 & 117.5 & 32.363 & 3 & 0 & 0.304 \\
\hline Natural disturbance & 0 & 1.4 & 4 & 2.6 & 8.447 & 3 & 0.038 & 0.159 \\
\hline
\end{tabular}




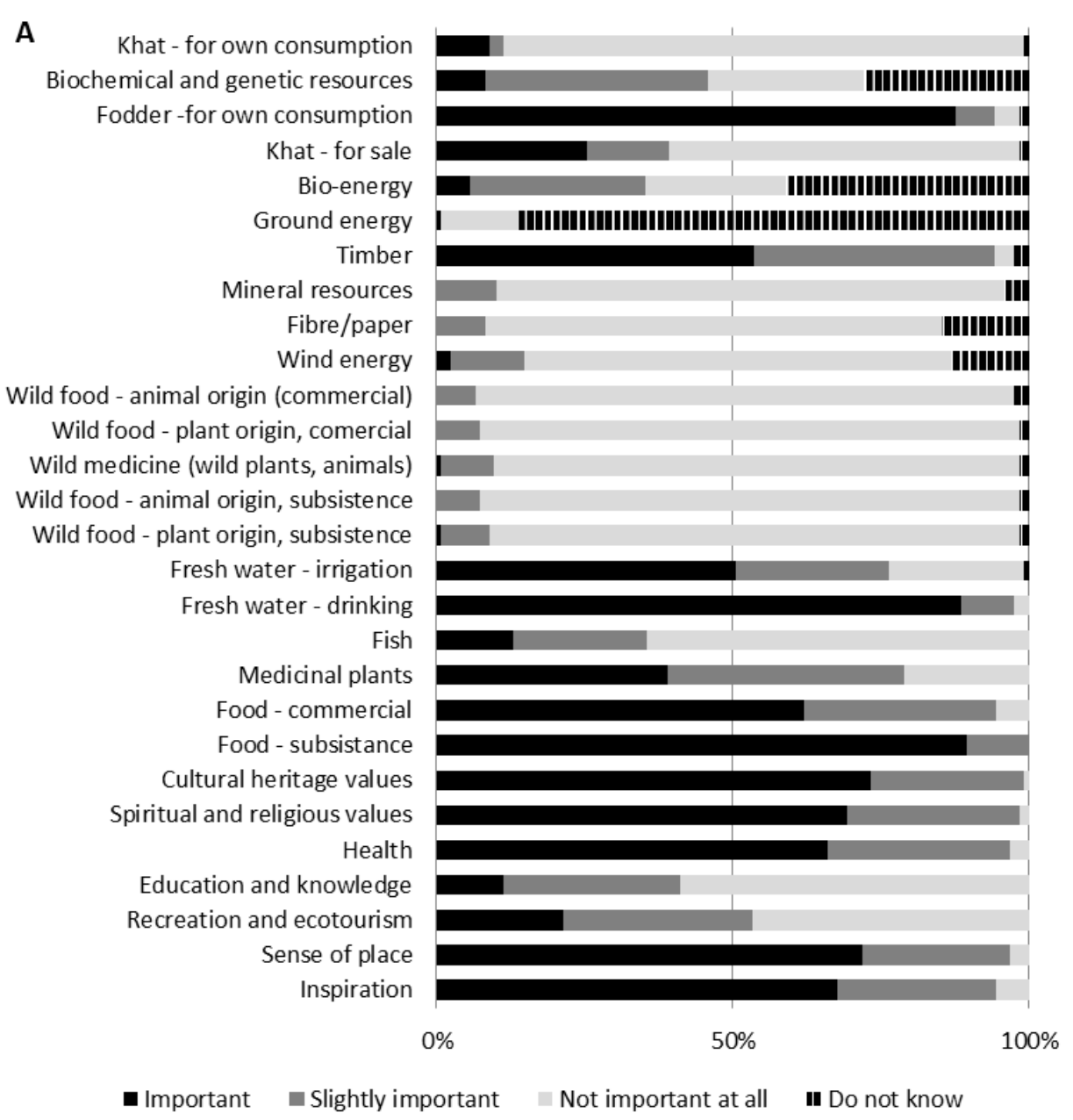

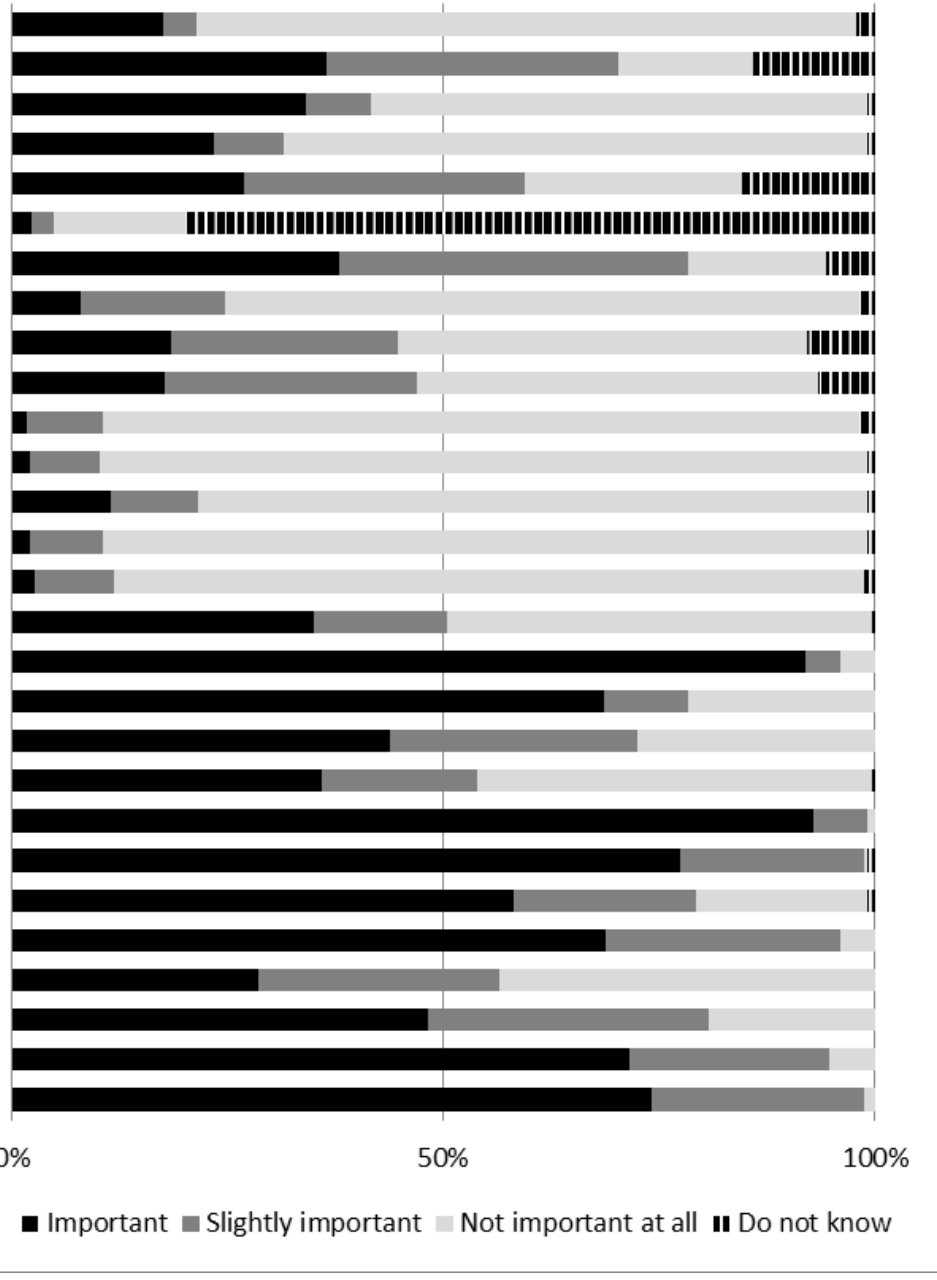

Figure 3. Cont. 


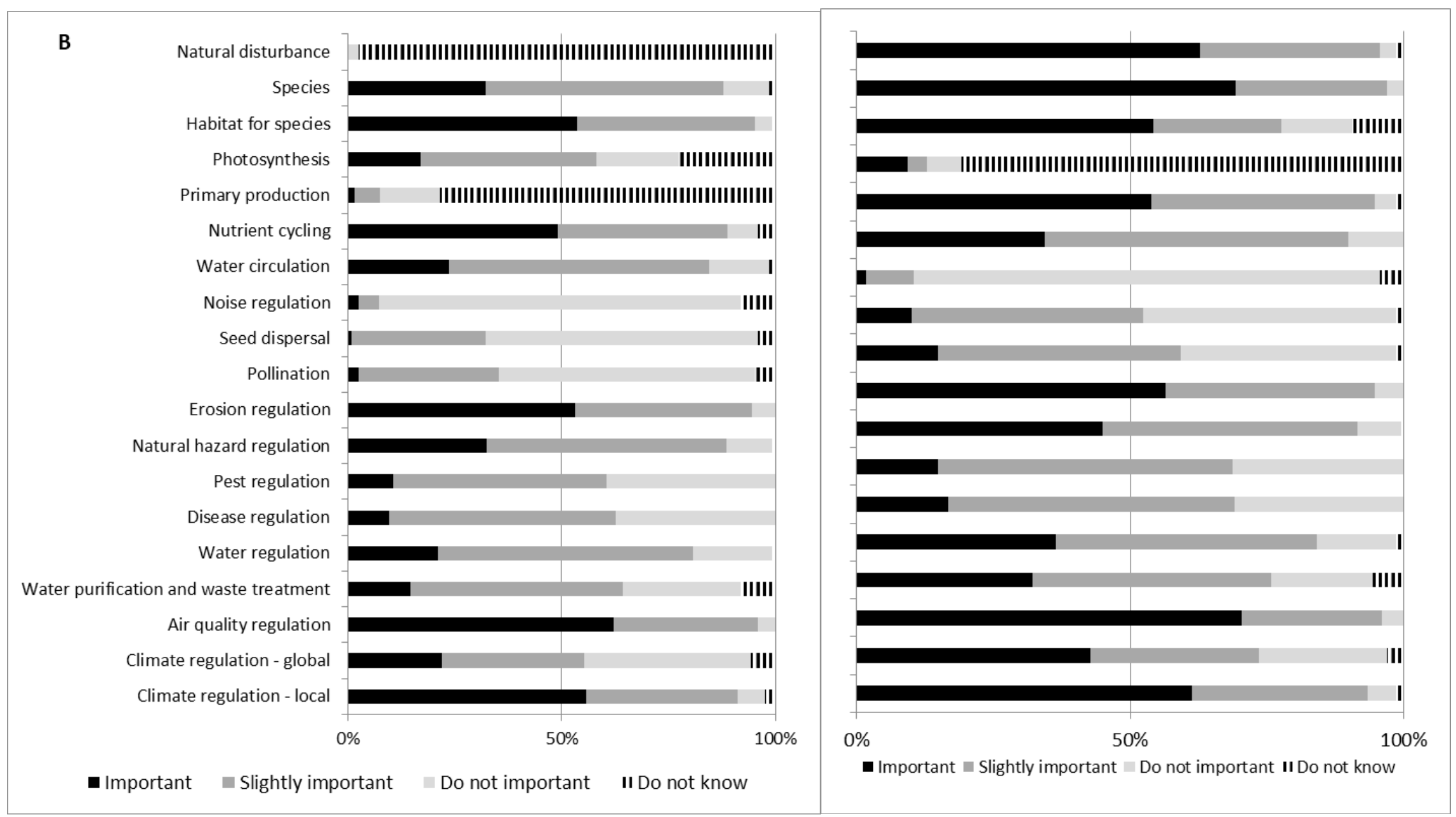

Figure 3. Importance of provisioning and cultural (A), supporting and regulating (B) services for rural (left) and urban (right) respondents. 


\subsection{Priority and Unwanted Land Covers According to Urban and Rural Respondents}

Urban respondents preferred a wider range of land covers, which they perceived as important for their livelihood, compared with rural respondents. The majority of urban respondents selected eight land covers, seven of which were natural and semi-natural areas, and one that was a built-up area (urban land cover). The natural and semi-natural areas included natural old-growth forest (59\% of respondents from this group), Afromontane undifferentiated forest $(52 \%)$, homegarden agroforestry $(92 \%)$, agroforestry shade-grown coffee $(65 \%)$, freshwater lake $(82 \%)$, river $(70 \%)$, and rural settlement $(52 \%)$ (Figure 4). In contrast, the majority of rural respondents selected three land covers as important for their personal livelihoods: urban land cover (65\% of respondents from this group), homegarden agroforestry $(80 \%)$, and agroforestry shade-grown coffee $(58 \%)$. Urban land cover was perceived as a place for better education and healthcare by rural respondents; in addition, urban respondents acknowledged it as a place for recreation and excitement.

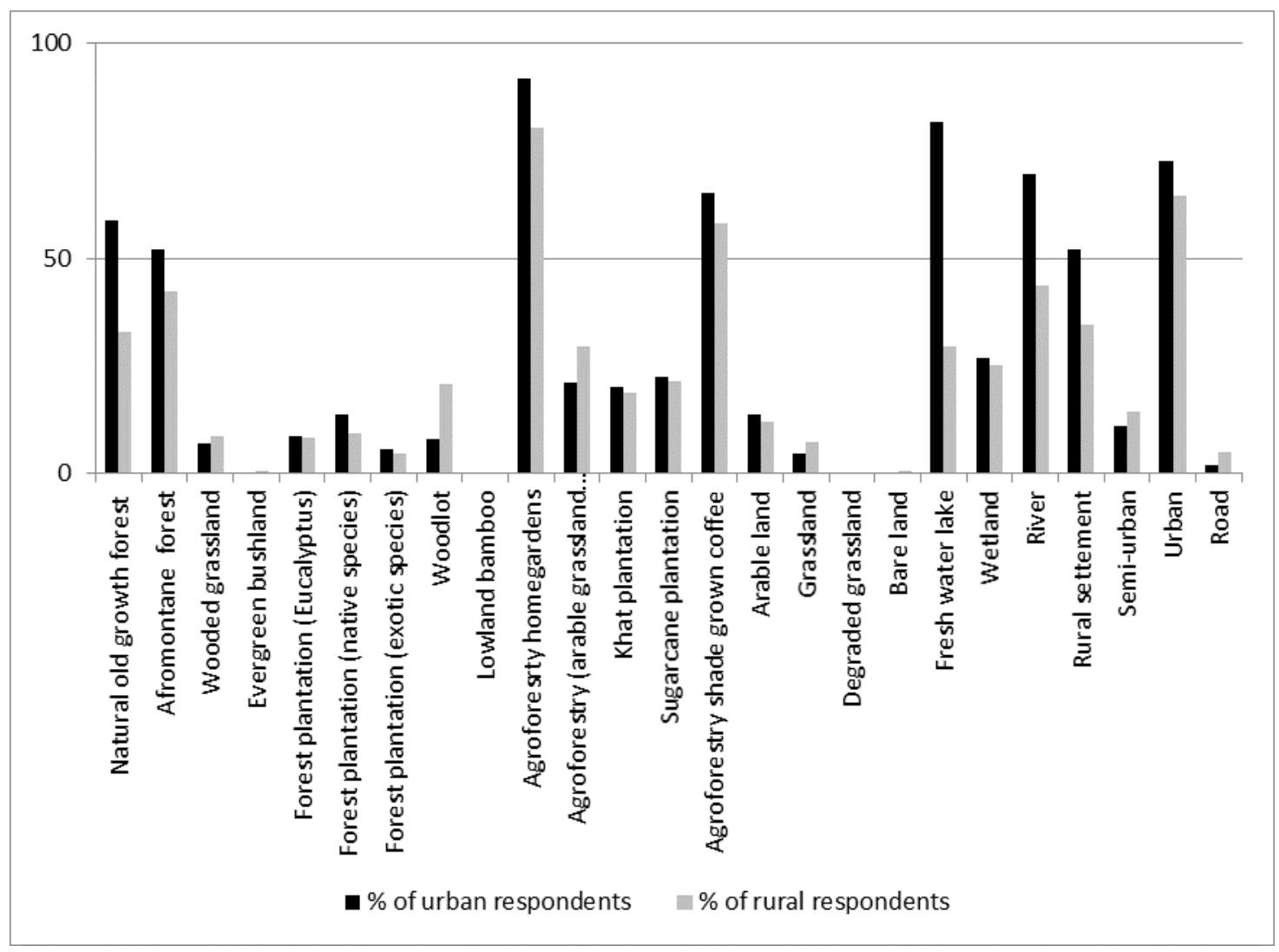

Figure 4. The perceived importance of land covers by urban and rural respondents.

Our results revealed that each selected land cover, except urban, was associated with bundles of ecosystem services that were important for the livelihoods of respondents (Table 4). For example, rural respondents associated homegarden agroforestry and agroforestry shade-grown coffee with multiple ecosystem services representing all four categories. The majority of respondents also associated these land covers with provisioning services, mainly for subsistence food and food for commercial purposes. Climate regulation at local and global levels, air quality regulation, and habitat for species were the prominent services associated with six priority land covers.

The most unwanted land cover identified by the majority of both rural and urban respondents was the land cover representing land with severe soil erosion. Over $90 \%$ of both rural and urban respondents perceived it as an unproductive wasteland that negatively affected land productivity. 
Table 4. Bundles of ecosystem services associated with the priority land covers by both urban and rural inhabitants. Ecosystem services shown in bold were acknowledged as important for personal livelihood by both urban and rural respondents; the text in italics shows ecosystem services that were important for the livelihoods of rural respondents; the regular text indicates ecosystem services that were acknowledged by urban respondents as important for their livelihoods and associated with a specific land cover.

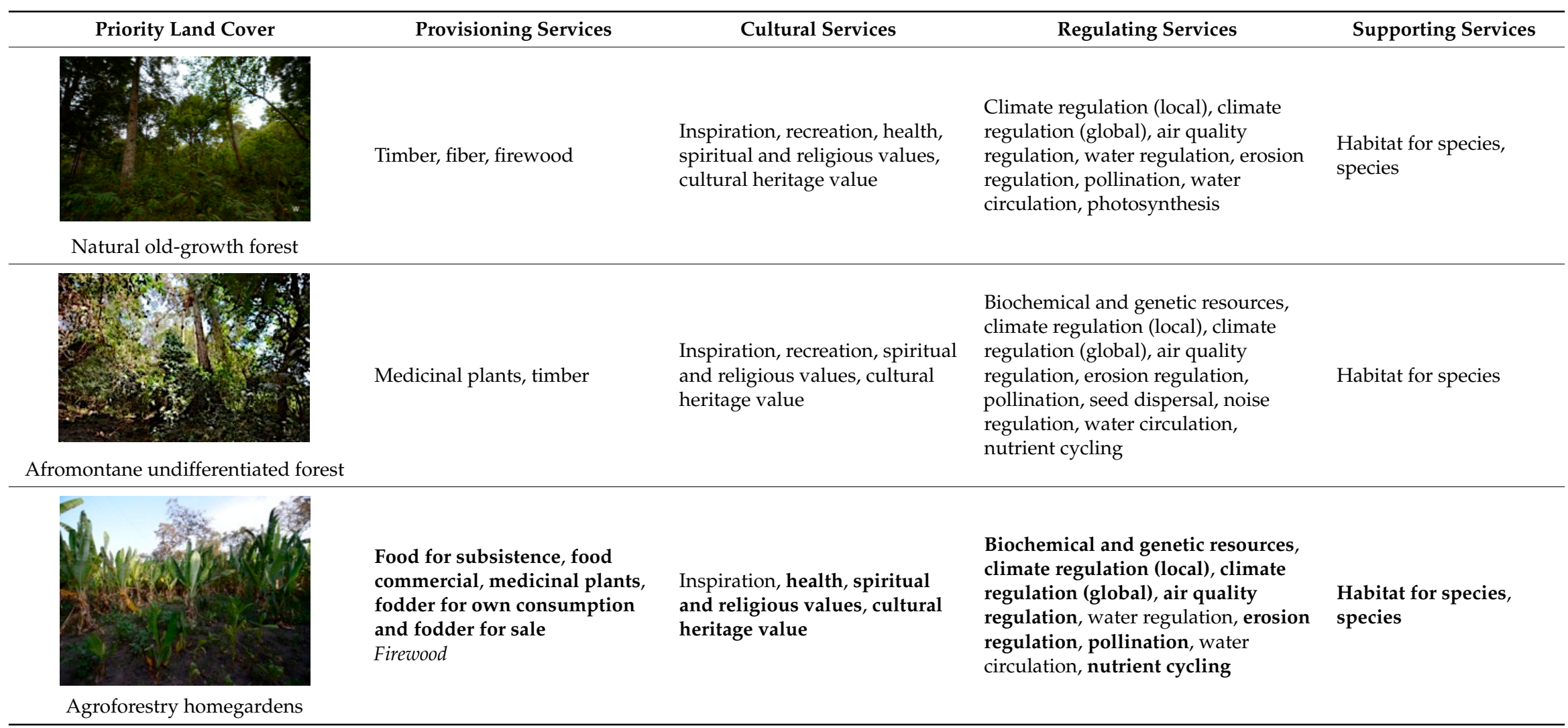


Table 4. Cont.

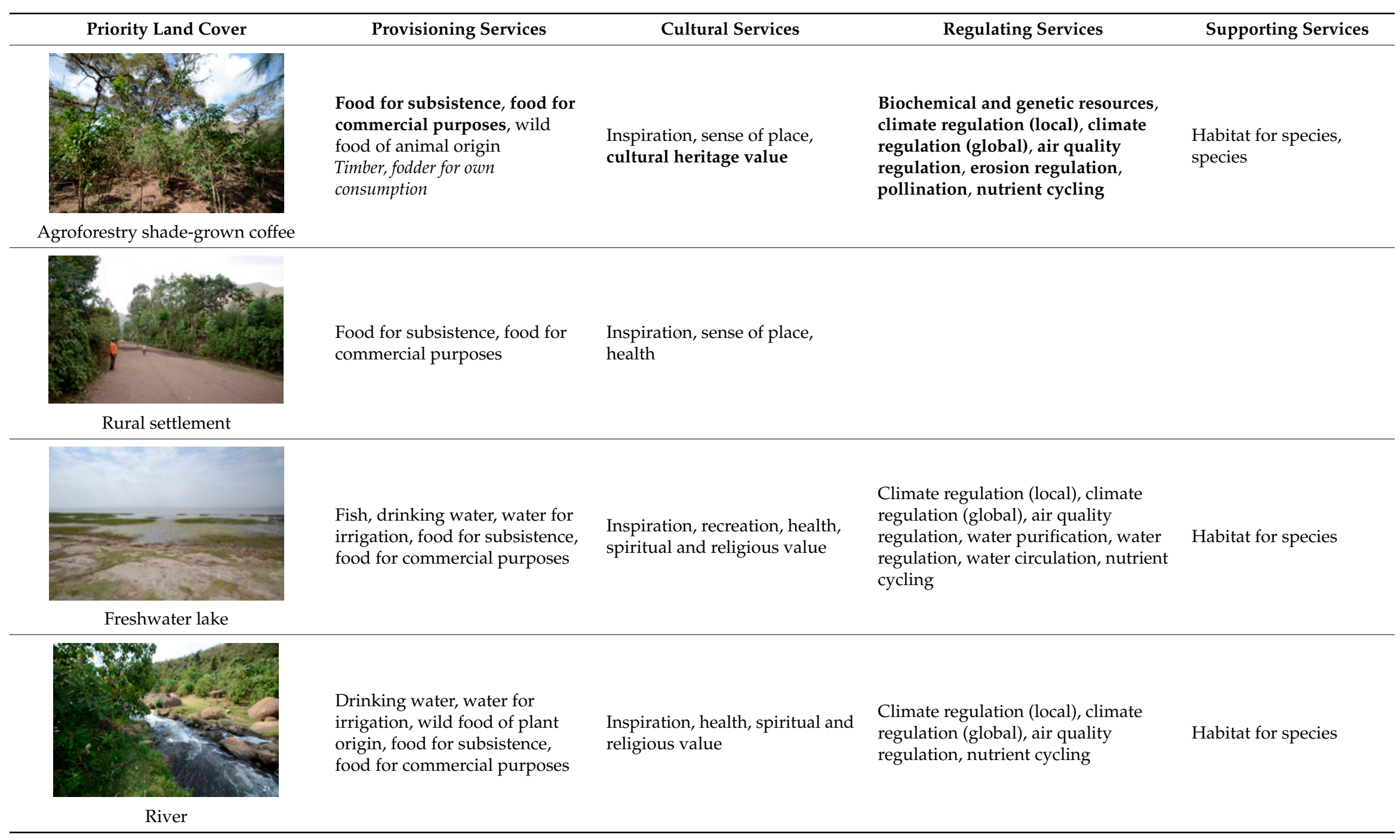




\subsection{Spatial Distribution of Priority and Unwanted Land Covers}

Analysis of the spatial distribution of the priority land covers shows that their area proportions were different across Sidama's three agroecological zones. Rural settlement occupied 31\% of the study area, while freshwater lake covered less than $2 \%$. Rural settlements were distributed more or less evenly across all of the agroecological zones in Sidama (Figure 5). In contrast, freshwater lake, agroforestry homegardens, agroforestry shade-grown coffee, and Afromontane forest were concentrated mainly in the sub-tropical Woyna Dega agroecological zone (Zone II in Figure 5). There was a clear difference among the agroecological zones regarding the total area of priority land covers. The most wanted land covers were dominantly represented in the sub-tropical Woyna Dega agroecological zone, with a total area proportion amounting to $61 \%$ to $70 \%$ for urban and $21 \%$ to $30 \%$ for rural respondents (Figure 6). Degraded land was the most unwanted land cover, which occupied approximately $4 \%$ of total study area, mainly in the dry Qolla agroecological zone.
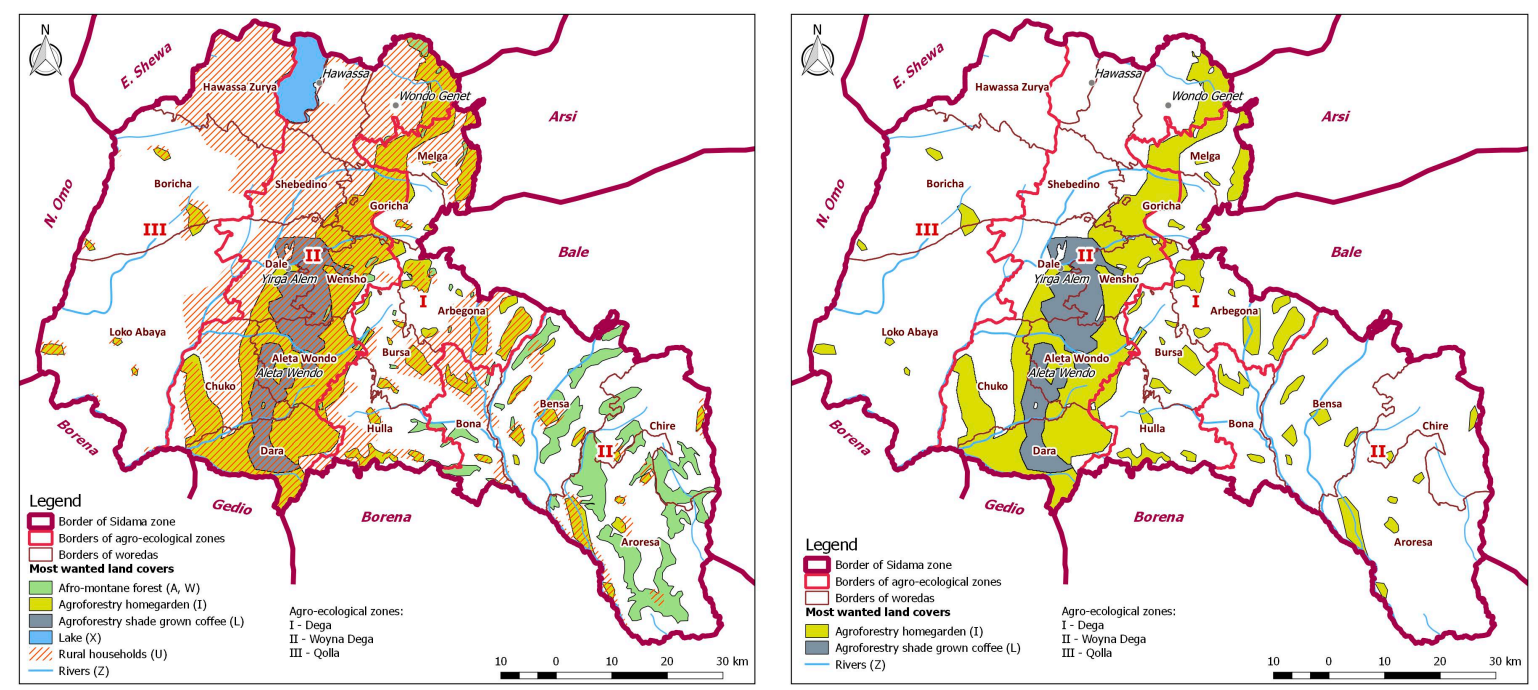

Figure 5. Distribution of the priority land covers, or natural and semi-natural areas, for urban (left) and rural (right) respondents in the different agroecological zones.
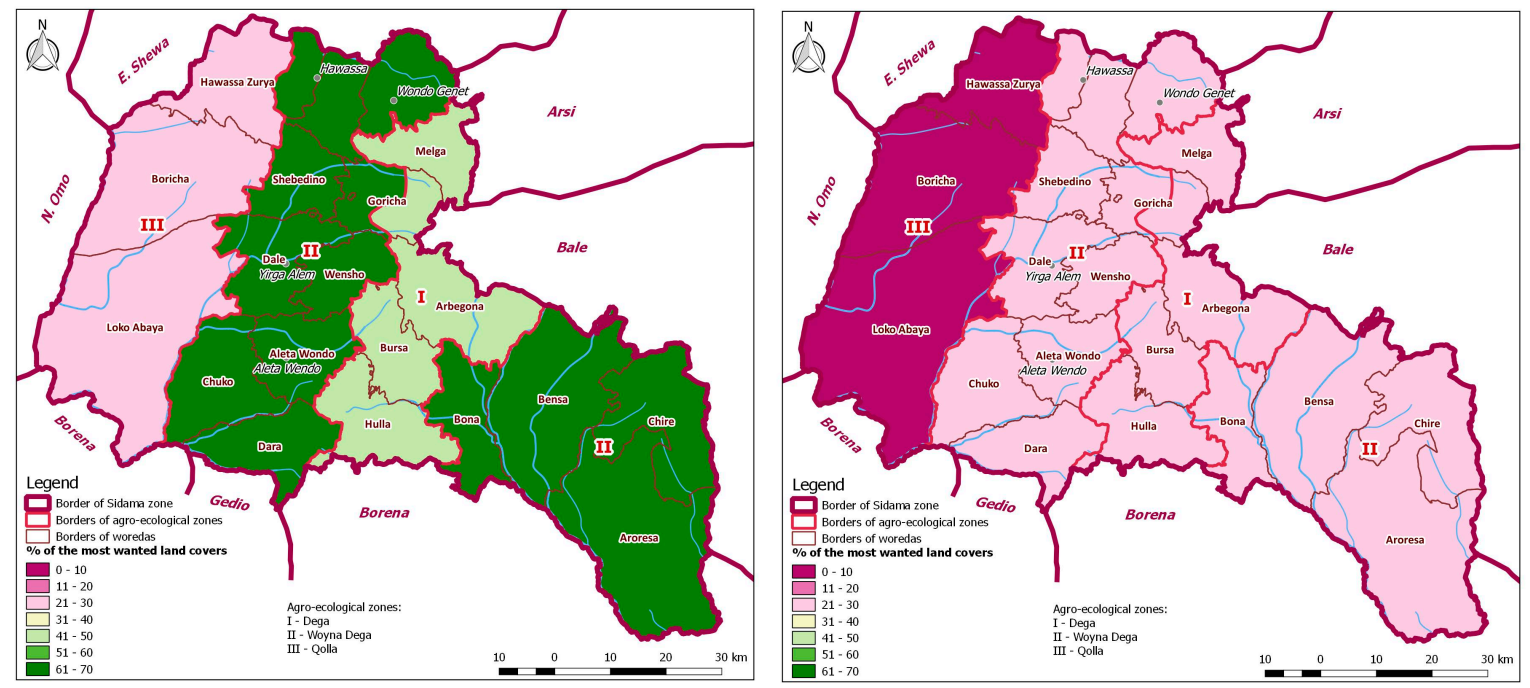

Figure 6. Area proportion of priority land covers for urban (left) and rural respondents (right) in each agroecological zone. 
The spatial distribution analysis of hotspots (Figure 7) showed that the highest proportion of hotspots area to the total surface area of each respective agroecological zone were in Woyna Dega $(56 \%)$ for urban respondents and in Dega (31\%) for rural respondents. The lowest proportion was in Qolla for both rural respondents $(<2 \%)$ and urban respondents $(27 \%)$.
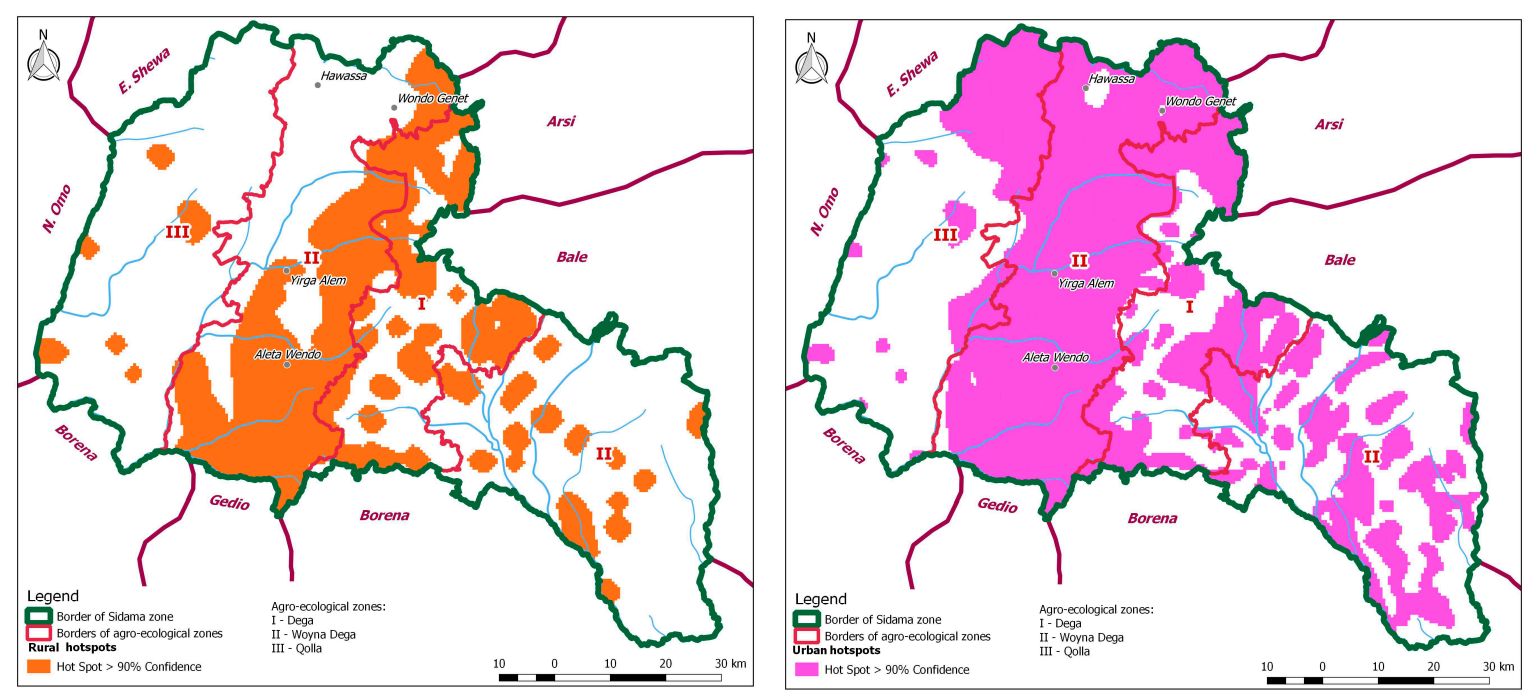

Figure 7. Spatial location of priority land covers' hotspots for livelihoods of urban (left) and rural (right) in the three agroecological zones.

\section{Discussion}

\subsection{Multiple Ecosystem Services from Priority Land Covers for Rural and Urban Livelihoods}

Our study shows that all four categories of ecosystem services (provisioning, cultural, regulating, and supporting) are important for the livelihoods of both urban and rural citizens. The majority of respondents associated the appreciated services with seven land-cover types, representing terrestrial natural/semi-natural areas and aquatic ecosystems. The results also show that urban respondents selected more diverse ecosystem services as well as natural and semi-natural areas compared with rural residents (Table 4). This could be explained by urban dwellers often being more educated, better informed, and needing more diverse tangible and intangible products in order to satisfy their multiple needs. Rural residents are focused on the most crucial services that are urgently needed to meet their daily needs, such as food and fodder, as well as their cultural identity.

Our attempt to attribute different ecosystem services to the five types of capital of SLA shows that all of the priority land covers represented by natural and semi-natural areas were perceived by the respondents as those that deliver services associated with the maintenance of natural capital (Figure 8). For example, the majority of respondents associated diverse and multiple supporting services to all selected land covers except rural settlements, acknowledging their importance for personal livelihoods. This reflects that natural capital is perceived as one of the most important types of capital for securing the livelihoods of both rural and urban residents. At the same time, the deforestation rate is high in the study area, especially in the Woyna Dega agroecological zone, which hosts the largest area of priority land covers' hotspots for both urban and rural respondents. During our fieldwork, the government used the army to prevent the illegal logging and deforestation that is conducted to establish new farms in this agroecological zone in Sidama. This also illustrates the challenge of providing both agricultural products and securing biodiversity as natural capital [65], even if this capital is acknowledged by diverse groups of local residents as important for their livelihood. 


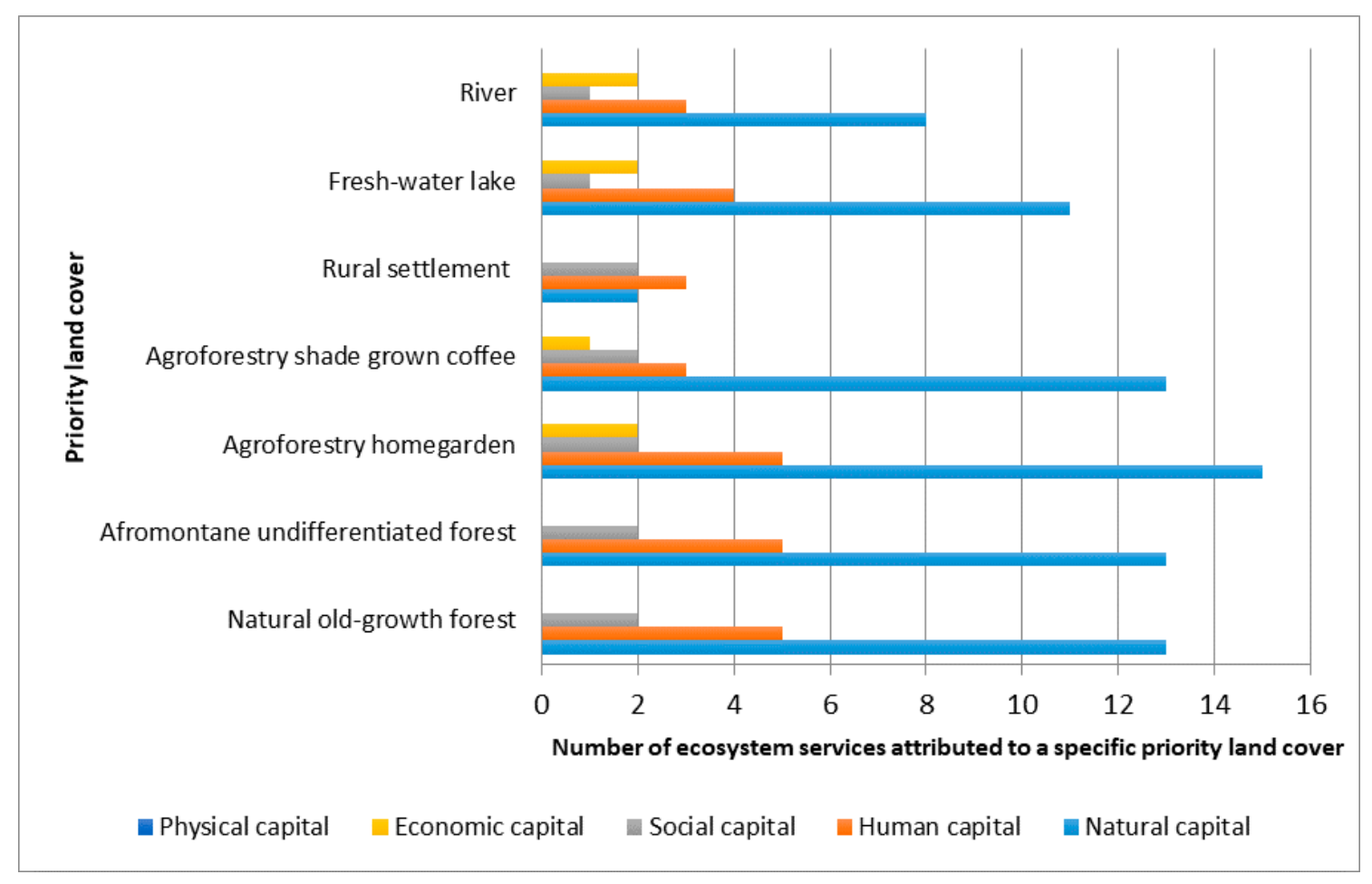

Figure 8. Contributions of priority land covers to the capital of sustainable livelihoods of both urban and rural residents.

Moreover, the priority land covers also deliver ecosystem services important for human, social, and economic capital. For example, natural old-growth forest was perceived as a place for inspiration and recreation, and as a provider of conditions for good health, spiritual, and religious values. Some land covers delivered ecosystem services that contribute to economic capital; for example, food or fodder for sale from agroforestry homegardens. In this case, we also acknowledge that some ecosystem services are social-ecological services due to the considerable human influence exerted, in both the past and present, on the composition, structure, and functions of ecosystems [66,67]. In our study, three land covers (agroforestry homegardens, agroforestry shade-grown coffee, and rural settlements) were those that deliver social-ecological services as outcomes of mainly small-scale traditional farming.

Analyses of the spatial distribution of the priority land covers revealed that four land covers (Afromontane and old-growth natural forests as well as river and lake) have limited distributions across Sidama. Additionally, Afromontane and old-growth forests are remotely located and owned by the state, which make them difficult for the public to access. This is a consequence of the decline of natural forest from $40 \%$ to $3 \%$ during the 20th century [68,69], which is a process that is continuing in Ethiopia. At the same time, agroforestry homegardens and agroforestry shade-grown coffee are widely distributed in the study area. This makes these land covers crucial for the provision of ecosystem services that are important for the livelihoods of respondents from both groups.

\subsection{Land Management Strategies to Maintain Priority Land Covers}

A review of agricultural expansion and its impacts on tropical nature [65] predicted that conflicts between food production and biodiversity conservation will be intensified. This study suggests that at least two land management strategies are needed to maintain the priority land covers that sustain important assets for the livelihoods of both urban and rural people and biodiversity conservation: (1) maintaining traditional agroforestry land-use practices (agroforestry homegardens, 
agroforestry shade-grown coffee, and rural settlement); and (2) enhancing the protection and sustainable management of natural forest ecosystems (old-growth forest and Afromontane forest).

Regarding the first strategy, a range of traditional agroforestry practices allow smallholder farmers to balance and maintain natural, financial, human, and social assets, as was exemplified by agroforestry homegardens and agroforestry shade-grown coffee in this study (Figure 8), and thus to deliver essential livelihood outcomes [11,70]. For example, the presence of enset (Ensete ventricosum) in the photograph that was shown to respondents received high attraction from both rural and urban dwellers because enset products are used in many regions in Ethiopia. Multiple provisioning services (wood, dairy products, and food crops, including vegetables and fruits) provided by agroforestry homegardens are important for household nutrition, income, and food security [71-74], which helps farmers to diversify their household production and financial income [75]. Furthermore, the growing number of coffee kiosks in villages and towns that are supported by small-scale traders, mainly women, indicates the importance of coffee as a traditional cash crop for the viability of rural settlements' practicing traditional agroforestry at the local level, as well as for consumers at multiple levels [17].

Given the severe loss of natural habitats, traditional agroforestry contributes to biodiversity conservation in south and southwest Ethiopia [76]. The presence of native trees in agroforestry homegardens contributes to their conservation in the tropics [77-82]. Traditional agroforestry also provides connectivity among natural habitats by creating corridors between them, which may support the integrity of natural ecosystems and conserve some area-sensitive floral and faunal species [83].

The multiple ecosystem services associated with traditional agroforestry practices are co-produced through human-nature interactions, encompassing both ecological functions and traditional practices of rural communities $[40,84]$. Therefore, smallholder farmers are crucial for the sustainable management and maintenance of biodiversity as well as the composition of species and the structural arrangement of traditional agroforestry landscapes. Nevertheless, most traditional agroforestry practices in developing countries, including Ethiopia, are threatened by unsustainable land management $[85,86]$. The deterioration of traditional agroforestry landscapes is driven by population pressure, declining farm size, the global market, and socio-economic changes in society $[17,58,70,74,77,87]$. The introduction and integration of high-yield crops to increase farm productivity, the improvement of value-added production from food and traditional cash crops, and the creation of opportunities for off-farm employment to support the increasing population of landless farmers are essential $[61,88]$. Furthermore, participatory and action research that combines bottom-up and top-down approaches are needed to develop viable livelihood opportunities that are centered around the needs of rural communities $[5,11]$.

Regarding the second strategy to protect and manage sustainably natural forest ecosystems, our study also shows that natural capital is vital to sustaining the livelihoods of both urban and rural citizens. However, the protection of sufficient amounts of representative and functionally connected areas of natural forest is no longer feasible [89]. Given that remaining areas with higher levels of naturalness will continue to be exploited by smallholders using mixed-production systems, there is an urgent need to ensure the functionality of the remaining representative land covers as ecological infrastructure. This requires application of principles of systematic conservation planning and landscape restoration [90,91], as well as integrated community-based resource management aimed at satisfying both local needs and global demands to conserve biodiversity in protected area networks [65].

Documenting citizens' habitat selection using a bottom-up approach, as realized in this study, provides important input for both raising awareness about the relative role of different land covers and assets, and determining opportunities for spatial planning at different spatial scales. However, the conservation of natural landscapes also requires regional analyses of the needs and opportunities of biodiversity conservation actions [90,91]. To assess the states and trends of biodiversity among regions as a base for strategic and tactical spatial planning for either integrative (land-sharing such as agroforestry) or segregative (land-sparing such as protected area networks) approaches towards biodiversity conservation [92], there is need for systematic analyses [91] with at least two levels of 
spatial resolution. First, to support strategic planning, the states and trends for different potential natural vegetation types need to be estimated through gap analysis [90] by combining databases for different land cover types $[93,94]$ and for land-cover loss [68]. Second, to guide tactical spatial planning, there is a need to assess the opportunity for the spatial segregation traditional agroforestry and biodiversity conservation on the one hand, versus integration of them on the other. Spatial modeling of habitat network functionality is an effective approach to assess this $[95,96]$.

To conclude, we argue that, in a country such as Ethiopia where deforestation, land degradation, shortage of farmland, and food shortage are critical problems, traditional agroforestry practices, the sustainable management of natural forest ecosystems, and landscape restoration are important tools to reduce the vulnerability of livelihoods to stresses and shocks [1]. The development of a systems perspective on local development issues in rural Ethiopia that integrates a bottom-up approach, and the spatial planning of land covers with different functions is a potentially powerful tool in understanding the implications of management and governance options, strategies, and tools. This requires both evidence-based knowledge about ecological benchmarks [97] and the development of collaborative learning opportunities for stakeholders at multiple levels of governance $[5,98]$.

\section{Conclusions}

Responding to the dual challenges of sustaining the livelihoods of the poor and coping with the ongoing deterioration and loss of biodiversity in Africa, as well as conflicts among different land uses, both bottom-up knowledge production and regional spatial planning and design are needed. Focusing on the need for a bottom-up stakeholder perspective, we show how to identify and map land covers that deliver multiple ecosystem services that are important for the livelihoods of rural and urban citizens in the southern part of Ethiopia's Rift Valley as a case study. Urban respondents preferred a wider range of land covers representing both traditional land use in cultural landscapes and natural landscapes with old-growth forest, while the focus of rural respondents was more on agroforestry homegardens and shade-grown coffee. The differences between urban and rural residents were also reflected in the attributed importance to specific ecosystem services. To maintain the identified priority land covers and sustain the provision of ecosystem services for the livelihoods of both urban and rural people, at least two land management strategies are needed: (1) maintaining traditional agroforestry land-use practices; and (2) enhancing the functionality of protected area networks and sustainable management of natural forest ecosystems. Additionally, integrated planning is needed that considers both rural community-based resource management focusing on local needs for employment and products, and global demands to conserve biodiversity.

Author Contributions: M.E. and M.G. conceived and designed the study and performed the field work; all authors analyzed the data and wrote the paper

Acknowledgments: Funding for this study was granted by FORMAS (grant number 2011-1737) to Per Angelstam. The work of Diana Surová was funded by National funds through the FCT (Foundation for Science and Technology) under the project UID/AGR/00115/2013 and the scholarship SFRH/BPD/77649/2011.

Conflicts of Interest: The authors declare no conflict of interest.

\section{References}

1. Anonymous. Summary for Policymakers of the Regional Assessment Report on Biodiversity and Ecosystem Services for Africa of the Intergovernmental Science-Policy Platform on Biodiversity and Ecosystem Services; IPBES: Bonn, Germany, 2018.

2. Millennium Development Goals Report: Lessons Learned from Implementing the MDGS. Available online: https:/ / www.afdb.org/fileadmin/uploads/afdb/Documents/Publications/MDG_Report_2015.pdf (accessed on 1 April 2018).

3. Chandy, L.; Penciakova, V.; Ledlie, N. Africa's Challenge to End Extreme Poverty by 2030: Too Slow or Too Far behind? Available online: https:/ /www.brookings.edu/blog/up-front/2013/05/29/africas-challengeto-end-extreme-poverty-by-2030-too-slow-or-too-far-behind/ (accessed on 1 December 2017). 
4. Intergovernmental Panel on Climate Change (IPCC). Climate Change; Intergovernmental Panel on Climate Change: Geneva, Switzerland, 2007.

5. Angelstam, P.; Barnes, G.; Elbakidze, M.; Marsh, A.; Marais, C.; Mills, A.; Polonsky, S.; Richardson, D.M.; Rivers, N.; Shackleton, R.; et al. Collaborative learning to unlock investments for functional ecological infrastructure: Bridging barriers in social-ecological systems in South Africa. Ecosyst. Serv. 2017, 27, $291-304$. [CrossRef]

6. Sigwela, A.; Elbakidze, M.; Powell, M.; Angelstam, P. Defining core areas of ecological infrastructure to secure rural livelihoods in South Africa. Ecosyst. Serv. 2017, 27, 272-280. [CrossRef]

7. Feleke, S.T.; Kilmer, R.L.; Gladwin, C.H. Determinants of food security in southern Ethiopia at the household level. Agric. Econ. 2005, 33, 351-363. [CrossRef]

8. USAID. Agriculture and Food Security. Available online: https://www.usaid.gov/ethiopia/agricultureand-food-security (accessed on 25 September 2017).

9. World Bank. Improved Food Security in Ethiopia; World Bank: Washington, DC, USA, 2016.

10. United Nations Development Programme (UNDP). Human Development Report; United Nations Development Programme: New York, NY, USA, 2015.

11. Gebrehiwot, M. Agroforestry Homegardens in Ethiopia: Rural Livelihoods in Transition. Ph.D. Thesis, Swedish University of Agricultural Sciences, Uppsala, Sweden, 2017.

12. Lemenih, M.; Kassa, H. Re-greening Ethiopia: History, challenges and lessons. Forests 2014, 5, 1717-1730. [CrossRef]

13. Didita, M.; Nemomissa, S.; Gole, T.W. Floristic and structural analysis of the woodland vegetation around Dello Menna, Southeast Ethiopia. J. For. Res. 2010, 21, 395-408. [CrossRef]

14. Fekadu, G. Forest loss and climate change in Ethiopia. Res. J. Agric. Environ. Manag. 2015, 4, $216-224$.

15. Valentini, R.; Arneth, A.; Bombelli, A.; Castaldi, S. A full greenhouse gases budget of Africa: Synthesis, uncertainties, and vulnerabilities. Biogeosciences 2014, 11, 381-407. [CrossRef]

16. Badege, B. Deforestation and Land Degradation on the Ethiopian Highlands: A Strategy for Physical Recovery. In Proceedings of the International Conference on African Development Archives, Kalamazoo, MI, USA, 16-18 August 2001. Available online: http://scholarworks.wmich.edu/africancenter_icad_archive/2 (accessed on 15 June 2017).

17. Gebrehiwot, M.; Elbakidze, M.; Lidestav, G.; Sandewall, M.; Angelstam, P.; Habtemariam, K. From self-subsistence farm production to khat: Driving forces of change in Ethiopian agroforestry homegardens. Environ. Conserv. 2016, 43, 263-272. [CrossRef]

18. Tesfaye, A.; Wiersum, K.F.; Bongers, F. Spatial and temporal variation in crop diversity in agroforestry homegardens of southern Ethiopia. Agrofor. Syst. 2009, 78, 309-322.

19. Tesfaye, A.; Wirsum, K.F.; Bongers, F.; Sterck, F. Diversity and dynamics of homegarden agroforestry in southern Ethiopia. In Tropical Homegardens: A Time Test Examples of Sustainable Agroforestry; Kumar, B.M., Nair, M.A., Eds.; Springer: Dordrecht, The Netherlands, 2006; pp. 123-142.

20. Garedew, E. Land-Use and Land-Cover Dynamics and Rural Livelihood Perspectives, in the Semi-Arid Areas of Central Rift Valley of Ethiopia. Ph.D. Thesis, Swedish University of Agricultural Sciences, Umeå, Sweden, 2010.

21. Kumar, P.; Esen, S.E. Linking ecosystem services to strategic environmental assessment in development policies. Environ. Impact Assess. 2013, 40, 75-81. [CrossRef]

22. UNEP-WCMC. The State of Biodiversity in Africa: A Mid-Term Review of Progress towards 18779 the Aichi Biodiversity Targets; UNEP-WCMC: Cambridge, UK, 2016.

23. Villamagna, A.; Angermeier, P.; Bennett, E. Capacity, pressure, demand, and flow: A conceptual framework for analyzing ecosystem service provision and delivery. Ecol. Complex. 2013, 15, 114-121. [CrossRef]

24. Martínez-Harms, M.J.; Balvanera, P. Methods for mapping ecosystem service supply: A review. Int. J. Biodivers. Sci. Ecosyst. Serv. Manag. 2012, 8, 17-25. [CrossRef]

25. Egoh, B.; Reyers, B.; Rouget, M.; Richardson, D.; Le Maitre, D.; van Jaarsveld, A. Mapping ecosystem services for planning and management. Agric. Ecosyst. Environ. 2008, 127, 135-140. [CrossRef]

26. Reyers, B.; O'Farrell, P.J.; Cowling, R.M.; Egoh, B.N.; Le Maitre, D.C.; Vlok, J.H. Ecosystem services, land-cover change, and stakeholders: Finding a sustainable foothold for a semiarid biodiversity hotspot. Ecol. Soc. 2009, 14, 38. [CrossRef] 
27. Bagstad, K.J.; Villa, F.; Batker, D.; Harrison-Cox, J.; Voigt, B.; Johnson, G.M. From theoretical to actual ecosystem services: Mapping beneficiaries and spatial flows in ecosystem service assessments. Ecol. Soc. 2014, 19, 64. [CrossRef]

28. Colding, J.; Lundberg, J.; Folke, C. Incorporating Green-area User Groups in Urban Ecosystem Management. Ambio 2006, 35, 237-244. [CrossRef] [PubMed]

29. Tuvendal, M.; Elmqvist, T. Ecosystem services linking social and ecological systems: River brownification and the response of downstream stakeholders. Ecol. Soc. 2011, 16, 21. [CrossRef]

30. Daily, G.C. Nature's Services: Societal Dependence on Natural Ecosystems; Island Press: Washington, DC, USA, 1997.

31. Turner, R.K.; Daily, G.C. The Ecosystem Services Framework and Natural Capital Conservation. Environ. Resour. Econ. 2008, 39, 25-35. [CrossRef]

32. Chan, K.; Satterfield, T.; Goldstein, J. Rethinking ecosystem services to better address and navigate cultural values. Ecol. Econ. 2012, 74, 8-18. [CrossRef]

33. De Groot, R.S.; Wilson, M.A.; Boumans, R.M.J. A typology for the classification, description and valuation of ecosystem functions, goods and services. Ecol. Econ. 2002, 41, 393-408. [CrossRef]

34. Kaiser, B.; Roumasset, J. Valuing indirect ecosystem services: The case of tropical watersheds. Environ. Dev. Econ. 2002, 7, 701-714. [CrossRef]

35. Van Jaarsveld, A.S.; Biggs, R.; Scholes, R.J.; Bohensky, E.; Reyers, B.; Lynam, T.; Musvoto, C.; Fabricius, C. Measuring conditions and trends in ecosystem services at multiple scales: The Southern African Millennium Ecosystem Assessment (SAfMA) experience. Philos. Trans. Biol. Sci. 2005, 360, 425-441. [CrossRef] [PubMed]

36. Norgaard, R. Ecosystem services: From eye-opening metaphor to complexity blinder. Ecol. Econ. 2010, 69, 1219-1227. [CrossRef]

37. Turner, K. A Pluralistic Approach to Ecosystem Services Evaluation. School of Environmental Sciences, UEA, Norwich, UK, 2010. Available online: http://cserge.ac.uk/sites/default/files/edm_2010_07.pdf (accessed on 5 April 2018).

38. Fraser, E.; Dougill, A.; Mabee, W.; Reed, M.; McAlpine, P. Bottom up and top down: Analysis of participatory processes for sustainability indicator identification as a pathway to community empowerment and sustainable environmental management. J. Environ. Manag. 2006, 78, 114-127. [CrossRef] [PubMed]

39. Chambers, R.; Conway, G. Sustainable Rural Livelihoods: Practical Concepts for the 21st Century; Discussion Paper 296; IDS; Sussex: Brighton, UK, 1992.

40. Garrido, P.; Elbakidze, M.; Angelstam, P.; Plieninger, T.; Pulido, F.; Moreno, G. Stakeholder perspectives of wood pasture ecosystem services: A case study from Iberian dehesas. Land Use Policy 2017, 60, 324-333. [CrossRef]

41. Garedew, E.; Sandewall, M.; Söderberg, U.; Campbell, B.M. Land-Use and Land-Cover Dynamics in the Central Rift Valley of Ethiopia. Environ. Manag. 2009, 44, 683-694. [CrossRef] [PubMed]

42. Amsalu, A.; Stroosnijder, L.; de Graaff, J. Long-term dynamics in land resource use and the driving forces in the Beressa watershed, highlands of Ethiopia. J. Environ. Manag. 2007, 83, 448-459. [CrossRef] [PubMed]

43. Reid, R.; Kruska, R.; Muthui, N.; Taye, A.; Wotton, S.; Wilson, C.; Mulatu, W. Land-use and land-cover dynamics in response to changes in climatic, biological and socio-political forces: The case of southwestern Ethiopia. Landsc. Ecol. 2000, 15, 339-355. [CrossRef]

44. Angelsen, A.; Jagger, P.; Babigumira, R.; Belcher, B.; Hogarth, N.; Bauch, S.; Börner, J.; Smith-Hall, C.; Wunder, S. Environmental Income and Rural Livelihoods: A Global-Comparative Analysis. World Dev. 2014, 64 (Suppl. 1), S12-S28. [CrossRef]

45. Elbakidze, M.; Angelstam, P.; Yamelynets, T.; Dawson, L.; Gebrehiwot, M.; Stryamets, N.; Johansson, K.; Garriod, P.; Naumov, V.; Manton, M. A bottom-up approach to map land covers as potential green infrastructure hubs for human well-being in rural settings: A case study from Sweden. Landsc. Urban Plan. 2017, 168, 72-83. [CrossRef]

46. Van Berkel, D.; Verburg, P. Spatial quantification and valuation of cultural ecosystem services in an agricultural landscape. Ecolog. Indic. 2014, 37, 163-174. [CrossRef]

47. Millennium Ecosystem Assessment (MA). Ecosystems and Human Well-Being: Synthesis; World Resources Institute Island Press: Washington, DC, USA, 2005.

48. Ellis, F. Rural Livelihoods and Diversity in Developing Countries; Oxford University Press: New York, NY, USA, 2000. 
49. Scoones, I. Livelihoods perspectives and rural development. J. Peasant Stud. 1998, 36, 171-196. [CrossRef]

50. Carney, D. Sustainable Livelihoods Approaches: Progress and Possibilities for Change; Department for International Development: Ottawa, ON, Canada, 2003.

51. Hussein, K. Livelihoods Approaches Compared: A Multi-Agency Review of Current Practice; Department for International Development: Ottawa, ON, Canada, 2002.

52. Krantz, L. The Sustainable Livelihood Approach to Poverty Reduction; SIDA: Stockholm, Sweden, 2001.

53. Scoones, I.; Wolmer, W. Livelihoods in Crisis? New Perspectives on Governance and Rural Development in Southern Africa; IDS Bulletin: Brighton, UK, 2003; Volume 34.

54. Morse, S.; McNamara, N. Sustainable Livelihood Approach: A Critique of Theory and Practice; Springer: Berlin/Heidelberg, Germany, 2013.

55. Cloud Security Alliance (CSA). Population Projection: Based on 2007; CSA: Addis Ababa, Ethiopia, 2011.

56. Seyoum, Y. A Sidama Nation: Introduction. In Arrested Development in Ethiopia: Essay of Underdeveloped, Democracy and Self-Determination; Seyoum, Y., Mohammed, H., Eds.; Red Sea: Trenton, NJ, USA, 2006.

57. Markos, T. State-Society Relations and Traditional Modes of Governance in Ethiopia: A Case Study of Sidama; Addis Ababa University: Addis Ababa, Ethiopia, 2014.

58. Gessesse, D.; Kinlund, P. Khat expansion and forest decline in Wondo Genet, Ethiopia. Swed. Soc. Anthropol. Geogr. 2008, 90, 187-203.

59. Tadesse, G.; Zavaleta, E.; Shennan, C. Coffee landscapes as refuge for native woody biodiversity as forest loss continues in southwest Ethiopia. Biol. Conserv. 2014, 169, 384-391. [CrossRef]

60. Senbeta, F.; Denich, M. Effects of wild coffee management on species diversity in the Afromontane rainforests of Ethiopia. For. Ecol. Manag. 2006, 232, 68-74. [CrossRef]

61. Tesfaye, A. Diversity in Homegarden Agroforestry Systems of Southern Ethiopia. Ph.D. Thesis, Wageningen University, Wageningen, The Netherlands, 2005.

62. Mell, I.C. Green Infrastructure: Concepts, Perceptions and Its Use in Spatial Planning. Ph.D. Thesis, Newcastle University, Newcastle, UK, 2010.

63. IBM Corp. IBM SPSS Statistics for Windows, version 24.0; IBM Corp: Armonk, NY, USA, 2016.

64. Getis, A.; Ord, J.K. The Analysis of spatial association by use of distance statistics. Geogr. Anal. 1992, 24, 189-206. [CrossRef]

65. Laurance, W.F.; Sayer, J.; Cassman, K.G. Agricultural expansion and its impacts on tropical nature. Trends Ecol. Evol. 2014, 29, 107-116. [CrossRef] [PubMed]

66. Huntsinger, L.; Oviedo, J.L. Ecosystem services are social-ecological servicesin a traditional pastoral system: The case of California's mediterraneanrangelands. Ecol. Soc. 2014, 19, 8. [CrossRef]

67. Lele, S.; Springate-Baginski, O.; Lakerveld, R.; Deb, D.; Dash, P. Ecosystem services: Origins, contributions, pitfalls, and alternatives. Conserv. Soc. 2013, 11, 343-358. [CrossRef]

68. Dessie, G.; Kleman, J. Pattern and magnitude of deforestation in the South Central Rift Valley Region of Ethiopia. Mt. Res. Dev. 2007, 27, 162-168. [CrossRef]

69. Potapov, P.; Hansen, M.C.; Laestadius, L.; Turubanova, S.; Yaroshenko, A.; Thies, C.; Smith, W.; Zhuravleva, I.; Komarova, A.; Esipova, E.; et al. The last frontiers of wilderness: Tracking loss of intact forest landscapes from 2000 to 2013. Sci. Adv. 2017, 3, e1600821. [CrossRef] [PubMed]

70. Tesfaye, A. Determinants of crop diversity and composition in enset-coffee agroforestry homegardens of southern Ethiopia. Agric. Rural Dev. Trop. Subtrop. 2013, 114, 29-38.

71. Garrity, D.P. Agroforestry and the achievement of the Millennium Development Goals. Agrofor. Syst. 2016, 61, 5-14.

72. Galhena, D.H.; Freed, R.; Maredia, K.M. Homegardens: A promising approach to enhance household food security and wellbeing. Agric. Food Secur. 2013, 2, 1-13. [CrossRef]

73. Howard, P.L. Gender and social dynamics in swidden and homegardens. In Tropical homegardens: A Time-Tested Example of Sustainable Agroforestry; Kumar, B., Nair, P.K.R., Eds.; Springer: Dordrecht, The Netherlands, 2006; Volume 3, pp. 159-184.

74. Wiersum, K.F. Diversity and change in homegarden cultivation in Indonesia. In Tropical Homegardens: A Time-Tested Example of Sustainable Agroforestry; Kumar, B., Nair, P.K.R., Eds.; Springer: Dordrecht, The Netherlands, 2006; Volume 3, pp. 13-24.

75. Kumar, B.M.; Naira, P.K.R. The enigma of tropical homegardens. Agrofor. Syst. 2004, 61, 135-152. 
76. Fischer, J.; Stott, J.; Law, B.S. The disproportionate value of scattered trees. Biol. Conserv. 2010, 143, $1564-1567$. [CrossRef]

77. Abdoellah, O.S.; Hadikusumah, H.Y.; Takeuchi, K.; Okubo, S. Parikesit Commercialization of homegardens in an Indonesian village: Vegetation composition and functional changes. Agrofor. Syst. 2006, 68, 1-13. [CrossRef]

78. Fernandes, E.C.M.; Nair, P.K.R. An evaluation of the structure and function of Tropical homegardens. Agric. Syst. 1986, 21, 279-310. [CrossRef]

79. Peyer, A.; Guidal, A.; Wiersum, K.F.; Bongers, F. Homegarden dynamics in Kerala, India. In Tropical Homegardens: A Time-Tested Example of Sustainable Agroforestry; Kumar, B., Nair, P.K.R., Eds.; Springer: Dordrecht, The Netherlands, 2006; Volume 3.

80. Harvey, C.A.; Villalobos, G. Agroforestry systems conserve species-rich but modified assemblages of tropical birds and bats. Biodivers. Conserv. 2007, 16, 2257-2292. [CrossRef]

81. Bhagwat, S.A.; Willis, K.J.; John, H.B. Agroforestry: A refuge for tropical biodiversity? Ecol. Evol. 2008, 23, 261-267. [CrossRef] [PubMed]

82. Bardhan, S.; Jose, S.; Biswas, S.; Kabir, K.; Rogers, W. Homegarden agroforestry systems: An intermediary for biodiversity conservation in Bangladesh. Agrofor. Syst. 2012, 5, 29-34. [CrossRef]

83. Jose, S. Agroforestry for ecosystem services and environmental benefits: An overview. Agrofor. Syst. 2009, 76, 1-10. [CrossRef]

84. Garrido, P.; Elbakidze, M.; Angelstam, P. Stakeholders' perceptions on ecosystem services in Östergötland's (Sweden) threatened oak wood-pasture landscapes. Landsc. Urban Plan. 2017, 158, 96-104. [CrossRef]

85. Kumar, B.M. Species richness and aboveground carbon stocks in the homegardens of central Kerala, India. Agric. Ecosyst. Environ. 2011, 140, 430-440. [CrossRef]

86. Montagnini, F.; Nair, P.K.R. Carbon sequestration: An underexploited environmental benefit of agroforestry systems. Agrofor. Syst. 2004, 61, 281-295.

87. Vos, W.; Meekes, H. Trends in European cultural landscape development: Perspectives for a sustainable future. Landsc. Urban Plan. 1999, 46, 3-14. [CrossRef]

88. Tsegaye, T. Labour Force Growth and Its Effects on Ethiopian Rural Economy: A Study of Growth Policy Options to Promote Agricultural Growth and Rural Development in Ethiopia. Available online: http: / / www.aigaforum.com/articles/Labour_Force_Growth.pdf (accessed on 20 September 2017).

89. Ethiopia Biodiversity and Tropical Forests. 118/119 Assessment. Available online: http://pdf.usaid.gov/ pdf_docs/Pnadm939.pdf (accessed on 15 March 2017).

90. Angelstam, P.; Yamelynets, T.; Elbakidze, M.; Prots, B.; Manton, M. Gap analysis as a basis for strategic spatial planning of green infrastructure: A case study in the Ukrainian Carpathians. Écoscience 2017, 24, 41-58. [CrossRef]

91. Angelstam, P.; Andersson, K.; Axelsson, R.; Elbakidze, M.; Jonsson, B.-G.; Roberge, J.-M. Protecting forest areas for biodiversity in Sweden 1991-2010: Policy implementation process and outcomes on the ground. Silva Fenn. 2011, 45, 1111-1133. [CrossRef]

92. Bollmann, K.; Braunisch, V. To integrate or to segregate: Balancing commodity production and biodiversity conservation in European forests. In Integrative Approaches as an Opportunity for the Conservation of Forest Biodiversity; European Forest Institute: Freiburg, Germany, 2013.

93. Friis, I.; Demissew, S.; Breugel, P. Atlas of the Potential Vegetation of Ethiopia; Royal Danish Academy of Science: Copenhagen, Denmark, 2010.

94. Kindt, R.; Lillesø, J.-P.B.; van Breugel, P.; Bingham, M. Potential Natural Vegetation of Eastern Africa: Description and Tree Species Composition for Other Potential Natural Vegetation Types. Available online: www.vegetationmap4africa.org (accessed on 3 July 2017).

95. Angelstam, P.; Naumov, V.; Elbakidze, M.; Manton, M.; Priednieks, J.; Rendenieks, Z. Wood production and biodiversity conservation are rival forestry objectives in Europe's Baltic Sea Region. Ecosphere 2018, 9. [CrossRef]

96. Naumov, V.; Manton, M.; Elbakidze, M.; Rendenieks, Z.; Priedniek, J.; Uglyanets, S.; Yamelynets, T.; Zhivotov, A.; Angelstam, P. How to reconcile wood production and biodiversity conservation? The Pan-European boreal forest history gradient as an "experiment". J. Environ. Manag. 2018, 218, 1-13. [CrossRef] [PubMed] 
97. Manton, M.; Angelstam, P. Defining benchmarks for restoration of green infrastructure: A case study combining the historical range of variability of habitat and species' requirements. Sustainability 2018, 10, 326. [CrossRef]

98. Lee, K.N. Compass and Gyroscope: Integrating Science and Politics for the Environment; Island Press: Washington, DC, USA, 1994. article distributed under the terms and conditions of the Creative Commons Attribution (CC BY) license (http:/ / creativecommons.org/licenses/by/4.0/). 